\title{
Ethnobotanical Important Plant Species of Kaya Kauma and Kaya Tsolokero
}

\author{
Jolly Rajat ${ }^{1^{*}}$ Joyce Jefwa $^{1,2}$, Joseph Mwafaida $^{1}$ and Lawrence Chiro ${ }^{2}$ \\ ${ }^{1}$ Pwani University .P.O. Box: 195-80108 KilifiCounty, Kenya. \\ ${ }^{2}$ National Museums of Kenya.P.O.Box:40568, Nairobi, Kenya.
}

Received: February 26, 2018; Accepted: March 22, 2018; Published: April 4, 2018

*Corresponding author: jollyrajat, Pwani University, Kenya.E-mail:jollyrajat@hotmail.com

\begin{abstract}
An ethnobotanical study was carried out in the sacred forests of Kaya Kauma in Kilifi county and Kaya Tsolokero in Junju location in Kenya between 2015 and 2016. Indigenous important plants used for food, medicine, construction, recreation, and aesthetics are still available in the wild. Most of the plant species are threatened by over harvesting, human encroachment and loss of traditional knowledge on how to use them. In the Kaya Kauma and Tsolokero ethnobotanical knowledge on important plants has contributed to the livelihood of the communities living around the area. These plant resources have provided vital materials for survival to humanity. However this ethnobotanical knowledge has not been well documented, and these significant plant species used by the community around these forests has not been reported. Knowledge on ethnobotany in these communities is diminishing with the passage of the older generation. This paper intends to document the important plant species used by the communities living around Kaya Kauma and Kaya Tsolokero. Data was collected using interviews and questionnaires from the residents and villagers living around both the forest. Kaya elders, men, women and youth were interviewed in this survey. A total of 477 useful plants species were mentioned in Kaya Kauma and Kaya Tsolokero. In Kaya Kauma 167 useful plants were mentioned compared to 312 useful plants for Kaya Tsolokero. These useful plants were important for food, medicinal, constructional, firewood, decoration, recreational, beekeeping and others. It also served in fulfilling the economic, medicinal, forage, constructional, apiary and more importantly medicinal applications to the dwelling population.
\end{abstract}

Keywords: Kaya Kauma; KayaTsolokero; Communities; Important plant species;

\section{Introduction}

Kaya is asacred forest of the Mijikenda people in the coastalregion of Kenya. The literal meaning of Kaya is a "Home". These forest have a fortified village at its centre which is called "Kaya Village". The concept of Kaya forest started way back in 16th Century and got over by 1940. But the remains of these forests are still there. They were built on the hill tops for defence. These forest site still stand as homes for ancestors and are maintained by a council of elders.[1]In kaya Kauma the community does not live in the kaya sites but the traditional rituals of the communities are still performed in the Kaya sites. The Kaya forest is considered to be an intrinsic source of ritual power and the origin of cultural identity. It is also a place of prayer for members of the Mijikenda ethnic group. The Kaya forests of coastal Kenya are thus one example of a phenomenon that has been described from many other African countries and from other continents [2].The traditional African people have used plants as food and feed and as medicine for generations. Synthetic chemicals and petroleum derivatives can replace many plant-derived medicines, and other products to replace wood, but there is no substitute for plantderived foods. Almost all human foods are plants or organisms that eat plants [3]. The human diets are based on fewer plant species yet there are over 350,000 plant species with 80,000 edible for humans. Out of these, only 150 plant species are actively cultivated and 30 of these plants produce $95 \%$ of human calories and proteins.The coastal forests of Kenya are part of a regional system and remnants of East African Coastal forests extending as far down as Mozambique [4] as part of the ZanzibarIn hambaneregional mosaic of white [5].Traditional important plants are still available in the wild and most are threatened by genetic loss and loss of traditional knowledge on how to use them. Many traditional cultivars have disappeared and are not known to present generation.[6] Indigenous knowledge is with the older generation and the youth have shown little interest in sustaining it. There is therefore danger in completely loosing this important knowledge on important flora and their use.

The coastal forests of Kenya are rich in biodiversity of flora and fauna [7]accounting for more than $50 \%$ of Kenya's rare trees [8].These forests harbour wild germ plasm of food and medicine and exhibits a very high level of biodiversity endemism and rarity in a significant number of biological groups[9].As a part of this system and remnants of once much more extensive forest on the Kenya coast, the coastal sacred forests, Kayas, display high biodiversity values in terms of diversity, endemism and rarity. The latest estimates show that Kayas constitute about $5 \%$ of the remaining coastal closed forest cover of Kenya estimated to be about 67,000 ha, with high biodiversity values of 7 out of the 20 sites with the highest conservation status[10]. The forests are inhabited as sacred places and were homes to the Mijikenda community, a dominant ethnic community in the coastal region of Kenya [11]. 
They are nine distinct ethnic groups that include Giriama, Digo, Chonyi, Jibana, Kauma, Ribe, Rabai, Duruma, and Kambe referred to as the Mijikenda meaning "nine tribes" that speak closely related Bantu dialects sharing about $71 \%$ of their vocabulary [12].In Kenya, the richness of biodiversity in the Kaya forests was recognized in the 1980s [13] and the sacred forests are prominent on hills and other strategic sites blend culture and nature. Traditional restrictions were placed on access and the utilization of natural forest resources resulting to the kayas preserving and sustainingbiodiversity.Kaya forest patches are small in size, ranging in area from 10 ha to 400 hectares. To date, over 50 kayas have been identified in Kwale, Msambweni, Kinango, Kaloleni, Mombasa, Kilifi and Malindi. Information documented indicates rules to protect the site which included ban on cutting of live trees, restrictionof firewood collection and grazing of livestock. There is vast documentation of usefulness of plant biodiversity in Kenya such as the "Useful trees and shrubs for Kenya [14] and Traditional Food Plants of Kenya. [15]There is documentation in medicinal plants as in the "Traditional medicines in Africa, Medicinal trees of Bukusul and many others"[16]. To date most research on useful plants focused on documenting medicinal plants and their role to make a healthy community [17].This is the reason why a survey was conducted to determine the status of important plants.

\section{Materials and Methods}

\section{Site description}

Kaya Kauma, a primary Kaya of the Kauma community, is located in Jaribuni area in Kilifi County. The geographical position of this forest is $3^{\circ} 37.821 \mathrm{~S}$ and $39^{\circ} 44.189 \mathrm{E}$ at an altitude of $120 \mathrm{~m}$ above the sea level. The size of this forest is 100 ha in area and it exhibits a deciduous pattern of vegetation, sloping down in the north to "Ndzovuni" river. The forest exhibits a rich soil content of iron-ore deposit with the top layer of soil changing its colour to black due to the iron gravels. Iron ore mining is a major threat to this forest with deep pits spread all round and disposing the bare ground to gully erosion.

Kaya Tsolokerois located in Junju location of Kilifi County. It is a Kaya for the Jibana Community. The area of the forest is 35 hectares, geographical position is $3^{\circ} 50.802 \mathrm{E}$ and $39^{\circ} 44.645 \mathrm{~S}$ with a vegetation exhibiting an evergreen pattern with very thick forest and a variety of floral diversity. There is still a Kaya village inside the forest with dwelling population.

\section{Study Approach}

A survey on useful ethnobotanical important plant species around Kaya Kauma and Kaya Tsolokero was undertaken. A semistructured questionnaire was used to conduct a demographic survey on the population and the useful plants around the villages adjacent to Kayas. Important ethnobotanical plant species prevalent around both Kaya forests were taken into account with the help of interviews responses from the respondents. In Kaya Kauma 179 and 103 respondents from Kaya Tsolokero were interviewed respectively. The number of adjoining villages around two Kayas in all the four geographical directions was recorded from the area chief of Kauma and Junju location respectively. In all four directions 18 villages surrounding Kaya Kauma and 9 surrounding Kaya Tsolokero were surveyed. Recent population in each village was also recorded from the Chief's office. Semi-structured questionnaire were circulated in these villages to obtain the list of useful plants, parts used, habit of growth, frequency of usage, commercialization aspects, efforts on domestication for sustainability was accessed.

\section{Data Collection}

The prevalent local language was used as a media of communication apart from the prevalent language "Kiswahili" to get the best information from the respondents. Enumerators that were fluent with the local languages were trained to interview the respondents with the help of a local guide to conduct this survey. The villages that were chosen for the survey were around the forest in the radius of 5 to $8 \mathrm{~km}$ to capture the most knowledge of the flora. The Kaya elders, local herbalist, local leaders and a sample of adults and youth were randomly selected for interviews. The questionnaire focused on the general personal data of key informants, description of uses, habits and distribution of the important plants to the community and the corresponding uses and beliefs.

These data were evaluated and the results were manipulated to obtain general information on the prevalent knowledge on the plants that are important in the community. Important plants were noted according to the frequency of mentioning among the respondents that were categorized on the basis of gender, age and tribe.

\section{Results and Discussion}

The survey showed six (6) Mijikenda sub-tribes living around Kaya Kauma with the Kauma as the dominant group and five (5) sub-tribes living around Kaya Tsolokero with the Jibana community as the dominant. Fruits and vegetables were the most commonly used plants in the communities around both the Kaya forests. A total of 163important plants were listed from the population around Kaya Kauma and 213 useful plants around Kaya Tsolokero (Table 1). A total of 37 and 54 food plants were stated by the population of Kaya Kauma and Kaya Tsolokero respectively. A list of 73 medicinal plants and 114 medicinal plants used by the two population and 69 herbal plant species in Kaya Kauma and 48 in Kaya Tsolokero came to be known. Twelve (12) constructional plants were stated by the population around Kaya Kauma and 58 around Kaya Tsolokero respectively,24 useful firewood species in Kaya Kauma and 13 in Kaya Tsolokero. Two (2) useful plants were reported to be decorative around Kaya Kauma and 16 around Kaya Tsolokero. Two (2) of the useful plants were reported for bee-keeping around Kaya Kauma and 10 for Kaya Tsolokero. Eight (8) of the mentioned useful plants by the communities carried other uses.

From the survey undertaken 239 species of plants were mentioned as important by the communities around Kaya Kauma 
Table 1: Useful tropical plants ethno botanical species of Kaya kauma and Kaya Tsolokero

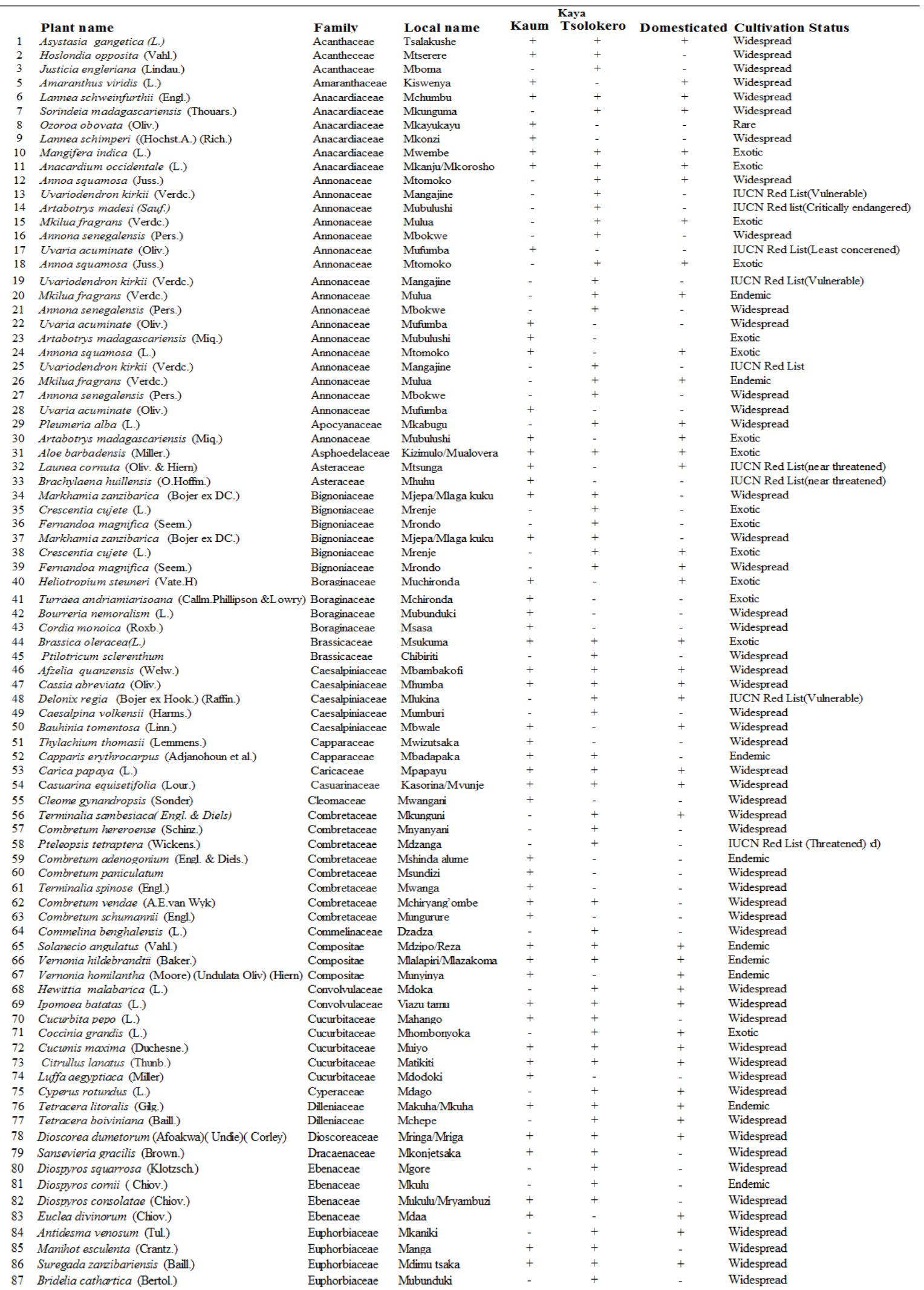


88 Euphorbia mikae (Pax ex Engl.)

89 Euphorbia dactilli (L)

90 Euphorbia pereskiifolia (Houllet ex Baill.)

91 Euphorbia trigona (Mill.)

92 Tragia furialis (Bojer)

93 Croton pseudopulchellus (Pax.)

95 Ricinus communis (L.)

95 Ricinus communis (L.)

96 Mildbraedia carpinifolia (Par

98 Oldfieldia somalensis (Chiov.)

98 Oldfieldia somalensis (Chiov.)

99 Albizia anthelmintica (Bro

100 Dializon orientale (Bak

101 Tamarindus indica

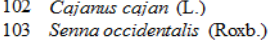

103 Senna occidentalis (Roxb.)

105 Dalbergia melanoxylon (Guill \& Perr.)

06 Mimosa pudica (L.)

107 Omocarpum kirkii (W.Sonder.)

108 Dichrostachys cinerea (L.)

109 Bombax rhodognophalon (Eng.)

110 Hymenaea verrucosa (Gaertn.)

111 Newtonia paucijuga (Harms.) (Brenan.)

112 Crotalaria laburnifolia (L.)

113 Lablab purproreus (L.)

114 Abrus precatorius (L.)

16 Senna siamea (Lam)

117 Vigna unguiculata (L.)

118 Erythrina sacleuxii (Andayi)

119 Albizia adianthifolia ((Schumach.)

120 Acacia ampliceps (Ursula K. Le Guin)

121 Acacia mellifera (Vahi)

122 Cynometra webberi (Baker $\mathrm{f}$ )

123 Brachystegia spiciformis (Benth.)

124 Flagelleria guinebsis (Schumach)

125 Gynocarpus americanus (Jacq.)

126 Vitex ferruginea (K. Schum. \& Thom.)

127 Hoslundia opposite (Vahl)

128 Ocimum gratissimum (L.)

129 Leucas glabrata (R.Br.)

130 Cyphostemma adenocaule (Cao\&Miller.)

131 Persea americana (Mill)

132 Hugonia castaneifolia (Engl)

133 Strychnos madagascariensis (Poir.)

134 Strychnos spinose (Lam)

135 Acoidocarpus zanzibaricus (Chiov.)

136 Acridocarpus alopeccuris (E.Launert.)

137 Nesogordonia holtzii (kavianyika.)

138 Corchorus tridens (L.)

139 Abelmoschus esculentus (L.)

140 Thespasia danis (Oliv.)

141 Hibiscus micranthus (L.)

142 Adensonia digitatata (L.)

143 Abutilon marritianum (Jacq.)

144 Waltheria indica (L.)

145 Melia azedarach (L.)

146 Azadirachta indica (A.Juss)

147 Trichilia emetic (Kotze)

148 Cissampelos pareira (Limn)

149 Tinospora oblongifolia (Eng1)

150 Grevea eggelingii (Milne.)

151 Artocarpus heterophyllus (L.)

152 Milicia excelsa (Welv.)

153 Hoplocoelum inoploeum (Radlk.)

154 Ficus benjamina (L.)

155 Ficus sycomorus (L)

156 Ficus bussei (Warb.)

157 Antiaris toxicaria (Pers.)

158 Ficus carica (L.)

159 Ficus lingua (Warb.)

160 Moringa oleifera (Lam)

161 Musa basjoo (Sieb.et.Zucc.)

162 Musa acuminate (L.)

163 Syzygium guineense (Willd.)

164 Psidium guajava (L.)

165 Eucalyptus comaldulensis (Dehnh.)

166 Brackenridgea zanguebarica (Oliv)

167 Ochna mossambicensis (Klotzsch)

168 Opillia amentacea (Roxb.)

169 Panicum virgatum. (Boutelou)(Claudio)

170 Passiflora edulis (Sims.)

171 Adenia globulosa (Engler.)

172 Flueggea virosa (Willd.)

173 Margaritoria discoidea (Baill)

174 Saccharum officinarum (L.)

175 Hordeum vulgare (L.)

176 Cymbopogon citratus(L.)

\begin{tabular}{|c|c|}
\hline Euphorbiaceae & Mtseketsa \\
\hline Euphorbiaceae & Chatsa \\
\hline Euphorbiaceae & Chatsamkulugo \\
\hline Euphorbiaceae & Chatsavunga \\
\hline Euphorbiaceae & Lwavi \\
\hline Euphorbiaceae & Musipiriti \\
\hline Euphorbiaceae & Myama wa nyika \\
\hline Euphorbiaceae & Mbono \\
\hline Euphorbiaceae & Mfundirangambi \\
\hline Euphorbiaceae & Mtupa \\
\hline Euphorbiaceae & Mbirandu \\
\hline Fabaceae & Мpoio \\
\hline Fabaceae & Mtumbwi \\
\hline Fabaceae & Mkwaju \\
\hline Fabaceae & Mbalazi \\
\hline Fabaceae & Mtsalafu \\
\hline Fabaceae & Muhumba \\
\hline Fabaceae & Mhingo \\
\hline Fabaceae & Kabodzebodze \\
\hline Fabaceae & Chitwadzi \\
\hline Fabaceae & Mkingiri \\
\hline Fabaceae & Mware \\
\hline Fabaceae & Mngolo \\
\hline Fabaceae & Mulea \\
\hline Fabaceae & Mfrimbi \\
\hline Fabaceae & Mhupu \\
\hline Fabaceae & Mtiri \\
\hline Fabaceae & Mpingwa \\
\hline Fabaceae & Mchilifi \\
\hline Fabaceae & Mkunde(Cowpeas) \\
\hline Fabaceae & Mbamba ngoma \\
\hline Fabaceae & Tsafwe/Mporojo/Mdzapi \\
\hline Fabaceae & Manemane \\
\hline Fabaceae & kikwata \\
\hline Fabaceae & Mfinda \\
\hline Fabaceae & Mrhi \\
\hline F hagellariaceae & Mchewa \\
\hline Hernandiaceae & Mpewa \\
\hline Lamiaceae & Mkuni \\
\hline Lamiaceae & Mvumbani \\
\hline Lamiaceae & Kavumbani \\
\hline Lamiaceae & Nyadzua \\
\hline Lamiaceae & Mchirawaloma \\
\hline Lauraceae & Avacado \\
\hline Linaceae & Mkuro \\
\hline Loganiaceae & Mkokola/Mkwakwa a \\
\hline Loganiaceae & Mbate /Mjaji \\
\hline Malpighiaceae & Mboho \\
\hline Malpighiaceae & Msinduzi \\
\hline Malvaceae & Mtobwe \\
\hline Makaceae & Chikosho \\
\hline Malvaceae & Mabenda \\
\hline Malvaceae & Mhoe \\
\hline Malvaceae & Karembeganga \\
\hline Malvaceae & Muyu \\
\hline Malvaceae & Mkorokoro \\
\hline Malvaceae & Muhangusa mavi \\
\hline Meliaceae & Msonobari \\
\hline Meliaceae & Mwarubaini \\
\hline Meliaceae & Mnwamadzi \\
\hline Menispermaceae & Mshondoha \\
\hline Menispermaceae & Mzikakoma \\
\hline Montinaceae & Mgandiza Pula \\
\hline Moraceae & Mfenesi \\
\hline Moraceae & Mvure \\
\hline Moraceae & Mfungohema \\
\hline Moraceae & Mvadapaa \\
\hline Moraceae & Mvumbamanga/Mga \\
\hline Moraceae & Mpeno \\
\hline Moraceae & Mguoguo \\
\hline Moraceae & Mpirapira \\
\hline Moraceae & Mdiro \\
\hline Moringaceae & Mzungi \\
\hline Musaceae & Mgomba \\
\hline Musaceae & Ndizi \\
\hline Myrtacaea & Mzambarau \\
\hline Myrtaceae & Mpera \\
\hline Myrtaceae & Mbuhgamu \\
\hline Ochnaceae & Mhoho \\
\hline Ochnaceae & Mdimu tsaka \\
\hline Opiliaceae & Msaro \\
\hline Panicum sp. & Maondo \\
\hline Passifloraceae & Mpesheni \\
\hline Passifloreceae & Mandari \\
\hline Phyllanthaceae & Mkwamba \\
\hline Phyllanthaceae & Kaguo \\
\hline Poaceae & Mua \\
\hline Poaceae & Mkunde \\
\hline Poaceae & Mzumaa \\
\hline
\end{tabular}

Endemic

Widespread

Endemic

Exotic

Exotic

Widespread

Exotic

IUCN Red List(Vulnerable)

Rare

Rare

Widespread

Widespread

Exotic

Exotic

Widespread

IUCN Red List(Near threatened)

Exotic

Widespread

UCN Red List(Least concerened)

Widespread

Widespread

IUCN Red List(Vulnerable)

Widespread

Widespread

Widespread

Endemic

Exotic

Widespread

Exotic

Widespread

Exotic

Exdemic

IUCN Red List(Vulnerable)

Endemic

Widesprea

Endemic

Widespread

Widespread

Widespread

Exotic

Widespread

Widespread

Endemic

Widespread

Widespread

UCN Red List(Least concerened)

Widespread

Endemic

Widespread

Widespread

Widespread

Widespread

Widespread

Widespread

Endemic

Endemic

Exotic

Wxotic

Exotic

Widespread

UCN Red List(Least concerened)

Exotic

IUCN Red List(Near threatened)

Exotic

Exotic

Widespread

Rare

Widespread

Exotic

Widespread

Exotic

Exotic

Exotic

Widespread

Exotic

Exotic

Widespread

Widespread

Widespread

Exotic

Widespread

Widespread

Widespread

Widespread

Widespread

Exotic

Exotic 


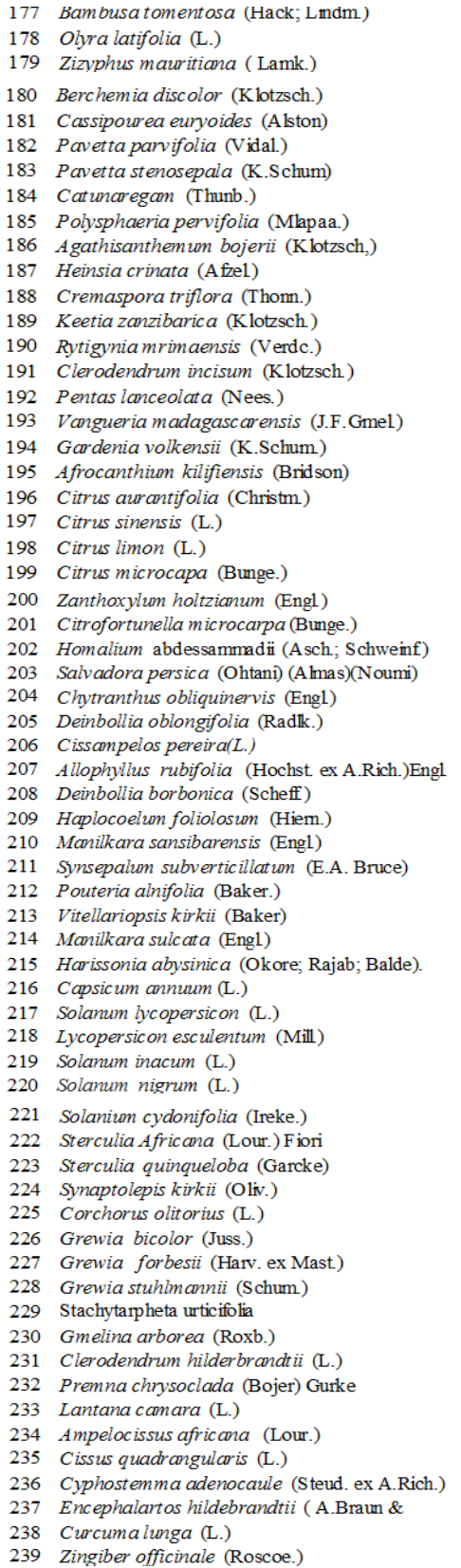

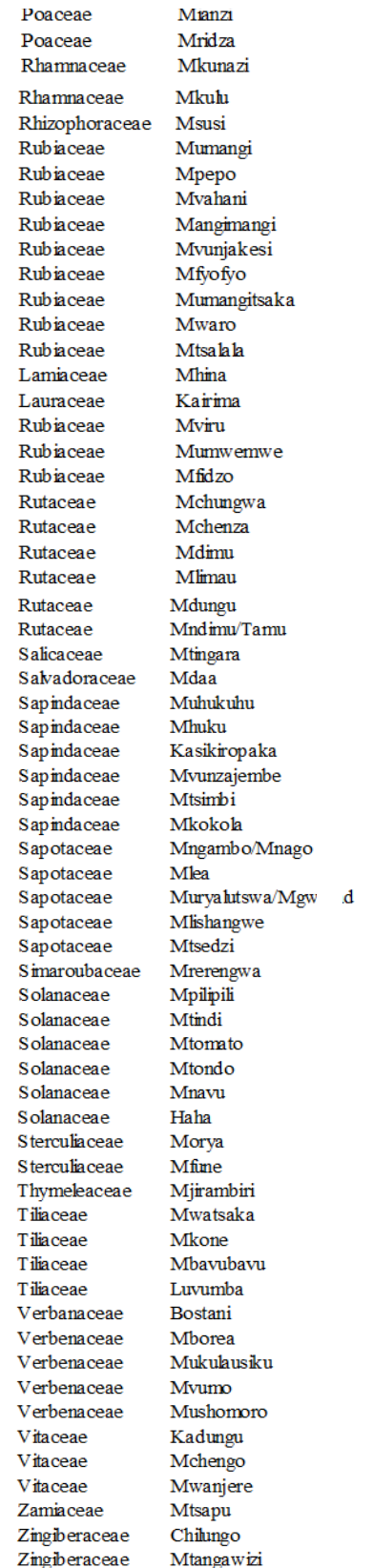

Exotic
Widespread
Exotic
Widespread
Widespread
Widespread
Widespread
Exotic
Widespread
Exotic
Widespread
Widespread
Endemic
Endemic
Widespread
Exotic
Widespread
Endemic
IUCN Red List(Vulnerable)
Exotic
Exotic
Exotic
Exotic
IUCN Red List (Threatened)
Widespread
Widespread
Widespread
IUCN Red List(Vulnerable)
Widespread
Exotic
Exotic
Widespread
Exotic
Widespread
Endemic
Widespread
IUCN Red List (Threatened)
Widespread
Widespread
Widespread
Exotic
Exotic
Widespread
Widespread
Rare
Widespread
Exotic
Widespread
Widespread
Widespread
Widespread
Endemic
Exotic
Exotic
Exotic
Endemic
Exotic
Widespread
Widespread
Widespread
IUCN Red List(Near threatened)
Exotic
Exotic

Table 2:Undocumented plants of Kaya Kauma and Kaya Tsolokero

\begin{tabular}{clllll}
\hline No & Local Name & $\begin{array}{l}\text { Parts } \\
\text { Used }\end{array}$ & $\begin{array}{l}\text { Tribes } \\
\text { mentioned }\end{array}$ & Habit & Kaya forest \\
\hline 1 & Mrerezi & Herb & Leaves & Kauma, Giriama & Kauma \\
2 & Mhuhumula & Climber & $\begin{array}{l}\text { Leaves } \\
\text { Kauma }\end{array}$ & Kauma \\
3 & Kaimbi & Herb & Leaves & Kauma & Kauma \\
4 & Kodzorera ajema & Climber & Leaves & Kambe & Kauma \\
5 & Mhuku & Herb & Fruit & Mchyoni & Tsolokero \\
6 & Mani & Climber & Leaves & Mchyoni & Tsolokero \\
7 & Mwazi & Tree & Fruit & Mgiriama & Tsolokero \\
8 & Kaboga & Climber & Leaves & Mchyoni & Tsolokero \\
9 & Mahuku & Tree & fruit & Mgiriama & Tsolokero \\
10 & Mkungi & Tree & Leaves & Mchyoni & Tsolokero \\
11 & Mkaniki & Herb & fruit & Mchyoni & Tsolokero \\
12 & Mpukusa & Tree & Leaves & Mjibana & Tsolokero \\
13 & Kahumwa & Tree & Roots & Mchyoni & Tsolokero \\
14 & Mvadapaa & Herb & Roots & Mjibana, Mchyoni & Tsolokero \\
15 & Mkakani & Herb & fruit & Mchyoni & Tsolokero \\
16 & Mhoho/Mho & Shrub & fruit & Kauma & Tsolokero \\
\hline
\end{tabular}

Citation: Jolly Rajat, Joyce Jefwa, Joseph Mwafaida, Lawrence Chiro(2018) Ethnobotanical Important Plant Species of Kaya Kauma 
and Kaya Tsolokero. These plants belonged to 15 families. The cultivation status of the mentioned plants showed 125 species that are wide spread around Africa, 24 as endemic in and around Kenya, 4 as rare species and 22 as threatened species by the International Unit of Conservation of Nature (IUCN).From the identified important species 136 plants were domesticated. $52 \%$ of the mentioned plants were cultivated around their homesteads and in their farms. Out of the plants stated by the population. sixteen (16) species of plants which were mentioned as important by the communities could not be assigned scientific names. These species were mentioned in their local language as Kauma by the communities around Kaya Kauma and Chonyi language by the communities around Kaya Tsolokero.

\section{Conclusion}

The important flora reported in this study was useful to the societies around kaya Kauma and Tsolokero. There is need therefore to categorize these important plants into their ethno botanical application. The data shall provide new insight to identify knowledge and, opportunity gaps for flora found in other kaya forests.

\section{References}

1. Abungu GO, Githitho A. Homelands of the mijikenda people: Sacred Mijikenda Kaya forests, Kenya. In: World Heritage: Benefits Beyond Borders. 2012:147-157. doi:10.1017/CB09781139567657.017.

2. Lehmann I, Kioko E. Lepidoptera Diversity, Floristic Composition and Structure of Three Kaya Forests on the South Coast of Kenya. J East African Nat Hist. 2005;94(1):121-163. doi:10.2982/00128317(2005)94[121:LDFCAS]2.0.CO;2.

3. Geraads D, Raynal J-P, Eisenmann V. The earliest human occupation of North Africa: a reply to Sahnouni et al. (2002). J Hum Evol. 2004;46(6):751-761. doi:10.1016/j.jhevol.2004.01.008.

4. Salman G, Abdula I. Development of the Mozambique and Ruvuma sedimentary basins, offshore Mozambique. Sediment Geol. 1995;96(12):7-41. doi:10.1016/0037-0738(95)00125-R.

5. MacFarlane DW, Kinzer AT, Banks JE. Coupled human-natural regeneration of indigenous coastal dry forest in Kenya. For Ecol Manage. 2015;354:149-159. doi:10.1016/j.foreco.2015.06.026.
6. Thiselton-DyerWT.Alphonse De Candolle. Nature.1893;48(1238):269271. doi:10.1038/048269c0.

7. Fancher RE. Francis galton's african ethnography and its role in the development of hispsychology. Br J Hist Sci. 1983;16(1):67-79.

8. Sundstrom E, Bell PA, Busby PL, Asmus C. ENVIRONMENTAL PSYCHOLOGY 1989-1994. Annu Rev Psychol. 1996;47(1):485-512. doi:10.1146/annurev.psych.47.1.485.

9. Anon. The World Health Report 1999: Making a Difference. WHO. 1999:136.

10. Nyangila JM. Museums and community involvement : A case study of community collaborative initiatives - National Museums of Kenya. In: Intercom. ; 2006:1-7.

11. Munene K. Museums in Kenya: Spaces for selecting, ordering and erasing memories of identity and nationhood. Afr Stud. 2011;70(2):224-245. doi:10.1080/00020184.2011.594630.

12. Cordell L, West C Van, Dean J. Wang et al 2007.pdf. Ann Bot. 2007;72(2):391-417.

13. Tumwesigye C, Yusuf SK, Makanga B. Structure and composition of benthic macro invertebrates of a tropical forest stream, River Nyamweru, western Uganda. Afr J Ecol. 2000;38(1):72-77. doi:10.10 46/j.1365-2028.2000.00212.

14. Ariga ES. Availability and Role of Multipurpose Trees and Shrubs in Sustainable Agriculture in Kenya. J Sustain Agric. 1997;10(2-3):25-35. doi:10.1300/J064v10n02_05.

15. Maundu P, Achigan-Dako E, Morimoto Y. Biodiversity of African vegetables. In: African Indigenous Vegetables in Urban Agriculture. ; 2009:65-104. doi:10.4324/9781849770019.

16. Okpoko AI. A history of African archaeology. African Archaeol Rev. 1991;9(1):111-118. doi:10.1007/BF01117217.

17. Tugume P, Kakudidi EK, Buyinza M, et al. Ethnobotanical survey of medicinal plant species used by communities around Mabira Central Forest Reserve, Uganda. J Ethnobiol Ethnomed. 2016;12(1). doi:10.1186/s13002-015-0077-4.

18. Force P.Pascal and philosophical method.In:The Cambridge Companion to Pascal. 2003:216-234. doi:10.1017/CCOL052180924X.013.

19. Talbert CH. Narrative Asides in Luke-Acts. Perspect Relig Stud. 1993;20(3):314-317. 